\title{
Two New Records of Andaspis Armored Scales (Hemiptera: Diaspididae) from Korea
}

\author{
Soo-Jung Suh
}

Yeongnam Regional Office, National Plant Quarantine Service, Korea

\section{Andaspis 속노린재목: 깍지벌레과의 한국미기록 2종에 대한 보교 \\ 서수정 \\ 국립식물검역원 영남지원}

\begin{abstract}
Two species of the genus Andaspis, Andaspis crawii (Cockerell) and Andaspis kashicola (Takahashi) are newly recorded in the Korean fauna of armored scales (Diaspididae). A key to species of Andaspis, illustrative photographs and information on the distribution and hosts of each species, are also provided to identify the specimens of Andaspis collected in Korea.
\end{abstract}

Key words: Andaspis crawii, Andaspis kashicola, New Records, Diaspididae, Korea

초 록: Andaspis속의 Andaspis crawii (Cockerell)와 Andaspis kashicola (Takahashi) 2종을 처음으로 국내분포로 보고하고, 한국산 Andaspis속의 종 동정에 필요한 검색표, 사진자료, 분포 및 기주 정보를 함께 기재하였다.

검색어: Andaspis crawii, Andaspis kashicola, 미기록종, 깍지벌레과, 한국

The genus Andaspis was named by MacGillivray (1921) and is comprised of 47 species worldwide (Miller et al., 2010). It is closely related to the genus Lepidosaphes, which also have oystershell shaped scale covers; some of its species were formerly placed in Lepidosaphes. However, the genus Andaspis differs from that genus primarily by the shape and position of the median lobes of the pygidium. These are usually exceptionally large, placed close together, with the inner edges short, diverging to the long oblique outer margins, with small gland spines between them (Williams and Watson, 1988). Knowledge of the Korean fauna of the armored scales (Diaspididae) began in 1928 with the publication of Machida and Aoyama (cited from the publication of Paik (2000)); so far, seventy two species have

*Comesponding author: suhsj97@korea.kr

Received January 31 2011; Revised March 15 2011;

Accepted March 162011 been documented (Paik, 1978; Paik, 2000; Kwon et al., 2003, Kwon et al., 2005; Suh and Hodges, 2007), but the genus of Andaspis has not been reported yet in Korea.

In the present work, the following two species of the genus of Andaspis are newly reported from the Republic of Korea: Andaspis crawii (Cockerell) and Andaspis kashicola (Takahashi). The Andaspis species collected during this survey do not have a club-shaped paraphysis arising from the middle basal part of median lobe, but rather a transverse sclerosis at the base of the median lobe or a unique shape of a lateral paraphysis of the median lobe. Also, only a few number of hosts were recorded for these species. Specimens of $A$. crawii live beneath the epidermis along the midrib, of the underside of the leaves of the collected hosts (Fig. 1: A). The other species, A. kashicola was collected on the underside of the leaves of its hosts (Fig. 1: C). Although the leaves of Castanopsis cuspidata were heavily infested with A. crawii, the scale did not seem to be causing serious damage to 
the tree (personal observation of Suh in 2008 and 2009).

A key to the Korean species of the genus Andaspis, information on the distribution and hosts of each species, and photographs of habitus and slide mounted adult female are provided. An asterisk $(*)$ is used to indicate a new host or distribution records. All the specimens of this study are deposited in the Collection of Yeongnam Regional Office, National Plant Quarantine Service in Busan, Korea.

\section{Genus Andaspis MacGillivray, 1921 안다스피스깍 지벌레속(신칭)}

Andaspis MacGillivray, 1921. Type species: Mytilaspis flava var. hawaiiensis Maskell.

Diagnosis: Andaspis with median lobes prominent and close together, with small gland spines between; the inner edges short, diverging to long oblique outer margins. The ventral paraphyses on the median lobes are variously shaped, often transverse and sometimes in addition, a club-shaped paraphysis arises from the basal angle or from the middle basal part of lobe. Second lobes usually reduced to points or lacking. Marginal macroducts enlarged, number 4-6 (Williams and Watson, 1988).

\section{Key to species of Andaspis from Korea (slide mounted adult female)}

1. Pygidial marginal macroducts numbering 5 on each side (Fig. 1: E). Without submedian dorsal ducts on the pygidium

A. crawii (Cockerell) (Fig. 1: A-B, D-F)

1b. Pygidial marginal macroducts numbering 6 on each side (Fig. 1: H). With submedian dorsal ducts on the pygidium A. kashicola (Takahashi) (Fig. 1: C, G-I)

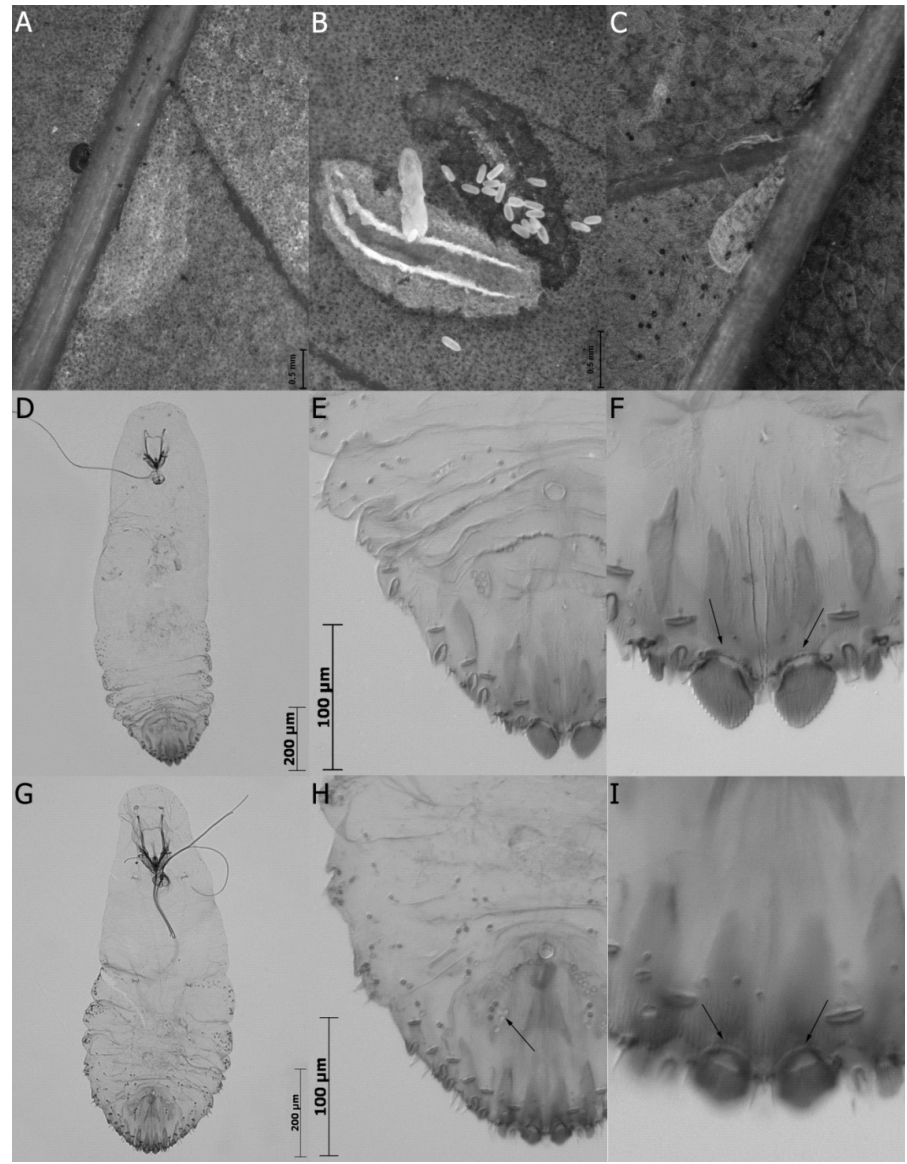

Fig. 1. A B. Andaspis crawii (Cockerell), female and egg living beneath the epidermis on the underside of the leaf of Castanopsis, C. $A$. kashicola (Takahashi), female cover on the underside of the leaf of Quercus; D F. A. crawii (Cockerell); G I. A. kashicola (Takahashi). 


\section{Andaspis crawii (Cockerell, 1896) 안다스피스깍지벌레 (신칭)}

Synonymy. Mytilaspis crawii Cockerell, 1896 [Japan: on Elaeagnus sp.]. Andaspis crawii; Rao and Ferris, 1952.

Diagnosis. Adult female much elongated and very slender, the abdomen only slightly lobed laterally. Median pygidial lobes of a distinctive form, triangular in form, and having a transverse sclerosis at the base of median.

Material examined. Korea. Jejudo: Harye-ri, Namwon-eup, Seogwipo-si, 19 adult females, on Castanopsis cuspidate, 12-iv-2007 (S.J. Suh). Jeollanamdo: Wando Arboretum, 10 adult females, on Castanopsis cuspidate, 17-vi-2008 (S.J. Suh).

Hosts. Elaeagnaceae: Elaeagnus sp; Fagaceae: Castanopsis cuspidata, Castanopsis kusanoi, Castanopsis sp., Castanopsis uraiana; Malvaceae: Pterospermum javanicum.

Distribution. *Korea, Japan, Taiwan and Indonesia.

\section{Andaspis kashicola (Takahashi, 1957) 종가시안다스피 스깍지벌레(신칭)}

Synonymy. Lepidosaphes kashicola Takahashi, 1957 [Japan: on Quercus glauca]. Andaspis kashicola; Takagi, 1960.

Diagnosis. Recognized by the presence of a transverse sclerosis at the base of median lobe and having submedian dorsal ducts on the pygidium.

Material examined. Korea. Jejudo: Napeup-ri, Awol-eup, Jeju-si, 6 adult females, on Quercus glauca, 23-vii-2008 (S.J. Suh). Gyeongsangbukdo: Sangyeok-dong, Buk-gu, Daegu-si, 1 adult female, on Quercus myrsinifolia, 18-iv-2009 (S.J. Suh).

Hosts. Betulaceae: Alnus incana, Alnus sp.; Fabaceae: Cytisus scoparius; Fagaceae: Castanea crenata, Castanopsis cuspidata, Quercus acuta, Quercus acutissima, Quercus glauca, *Quercus myrsinifolia, Quercus phillyraeoides, Quercus salicina, Quercus serrata; Pinaceae: Abies firma; Platanaceae: Platanus orientalis; Styracaceae: Styrax japonica.

Distribution. *Korea and Japan.

\section{Acknowledgements}

I would like to thank Dr. Takagi Sadao (Hokkaido University, Japan) for confirming the identification. I also thank Dr. Greg Evans (USDA/Animal and Plant Health Inspection, USA) for his useful editorial contributions to this draft manuscript. This research was supported by a grant from the National Plant Quarantine Service.

\section{Literature Cited}

Cockerell, T.D.A. 1896. Some coccidae found by Mr. Alex Craw in the course of his quarantine work at San Francisco. United States Department of Agriculture, Division of Entomology, Technical Series 4: 42-46.

MacGillivray, A.D. 1921. The Coccidae. 502 pp. Urbana, Ill. Scarab Co.

Kwon, G.M., M.J. Han and Y.H. Lee. 2003. The genus Aulacaspis Cockerell, 1893 (Sternorrhyncha, Diaspididae) in Korea. Kor. J. Appl. Entomol. 42(1): 15-20.

Kwon, G.M., M.J. Han and D.R. Choi. 2005. Scale insects (Sternorrhyncha) occurring on flowering plants in Korea. Kor. J. Appl. Entomol. 44(1): 51-59.

Miller, D.R., Y. Ben-Dov and G.A.C. Gibson. 2010. ScaleNet(webpage) http://www.sel.barc.usda.gov/scalenet/scalenet.htm. Accessed 15 January 2011.

Paik, W.H. 1978. Illustrated Flora and Fauna of Korea, vol. 22, Insecta (VI), Coccoidea. $481 \mathrm{pp}$. Ministry of Education.

Paik, J.C. 2000. Economic Insects of Korea 6, Homoptera (Coccinea). Insecta Koreana Suppl. 13. 193 pp. National Institute of Agricultural Science and Technology.

Rao, V.P. and G.F. Ferris. 1952. The genus Andaspis MacGillivray (Insecta: Homoptera: Coccoidea). (Contrib. No. 77). Microentomology 17: 17-32.

Suh, S.J. and G.S. Hodges. 2007. Identification of armored scales (Hemiptera: Diaspididae) on bamboos in Korea. J. Asia Pac. Entomol. 10(1): 1-3.

Takahashi, R. 1957. Some Japanese species of Diaspididae (Coccoidea, Homoptera). Transact. Shikoku Entomol. Soc. 5: 104-111.

Takagi, S. 1960. A contribution to the knowledge of the Diaspidini of Japan (Homoptera: Coccoidea) Pt. 1. Insecta Matsumurana 23: 67-100.

Williams, D.J. and G.W. Watson. 1988. The Scale Insects of the Tropical South Pacific Region. Pt. 1. The Armoured Scales (Diaspididae). 290 pp. CAB International Institute of Entomology, London. 